\title{
Meningkatkan Hasil Belajar Tema Organ Gerak Hewan dan Manusia Melalui Model Pembelajaran Discovery Learning Siswa Kelas V SD Inpres Ampiri Kabupaten
}

\section{Barru}

\author{
Hj. Ihade
}

Guru SD Inpres Ampiri, Kabupaten Barru, Sulawesi Selatan

\begin{abstract}
Abstrak
Tes diagnosis pada pembelajaran tema satu organ gerak hewan semester satu tahun pelajaran 2019-2020, menunjukkan hanya 67,64\% kategori rendah, dengan tuntas belajar 6 orang dengan persentase $54,5 \%$ dari jumlah peserta didik 11 orang, tidak mencapai kualitas rerata minimal 70 atau minimal cukup dengan tuntas belajar klasikal minimal $80 \%$ yang mencapai nilai KKM 70. Kemampuan guru hanya mencapai $58,33 \%$ dan aktivitas belajar peserta didik hanya mencapai $54,55 \%$, tidak mencapai standar keberhasilan tindakan lebih besar $62,5 \%$ atau minimal baik. Solusi penyelesaian masalah, melaksanakan model pembelajaran Discovery Learning pada pembelajaran tema organ gerak hewan dan manusia. Penelitian tindakan kelas ini menggunakan model dari Kemmis \& Taggart (dalam Sugiarti, 1997: 6), yaitu berbentuk spiral dari siklus yang satu ke siklus yang berikutnya. Setiap siklus meliputi planning (rencana), action (tindakan), observation (pengamatan), dan reflection (refleksi). Subyek penelitian ini adalah 12, lima orang laki-laki, tujuh orang berjenis perempuan. Data kualitatif dikumpul melalui lembar observasi aktivitas peserta didik dan kemampuan guru, sedang data kuantitatif dikumpul melalui tes hasil tindakan tiap akhir siklus. Hasil penelitian menunjukkan bahwa: (1) Hasil belajar peserta didik meningkat skor rata-rata siklus tiga adalah 80,45 kategori baik dengan tuntas belajar 9 orang dengan $81,8 \%$ dari total 11 orang peserta didik, dibandingkan rerata skor siklus dua 68,73 kategori kurang, meningkat secara positif selisih $11,72 \%$ dan kategori baik siklus tiga dari kurang siklus dua. (2) Kemampuan guru meningkat skor persentase selisih 19,44\% dan kategori baik siklus tiga dari cukup siklus dua. (3) Aktivitas peserta didik meningkat skor persentase selisih 20,45\% dan kategori baik siklus tiga dari cukup siklus dua.
\end{abstract}

Kata Kunci: hasil belajar, organ gerak hewan dan manusia, model pembelajaran, discovery learning

\section{Pendahuluan}

Menurut hasil tes diagnosis pada pembelajaran tema satu organ gerak hewan semester satu tahun pelajaran 2019-2020, menunjukkan hanya 67,64\% kategori rendah, dengan tuntas belajar 6 orang dengan persentase 54,5\% dari jumlah peserta didik 11 orang, tidak mencapai kualitas rerata minimal 70 atau minimal cukup dengan tuntas belajar klasikal minimal $80 \%$ yang mencapai nilai KKM 70. Kemampuan guru hanya mencapai 58,33\% dan aktivitas belajar peserta didik hanya mencapai $54,55 \%$, tidak mencapai standar keberhasilan tindakan lebih besar $62,5 \%$ atau minimal baik (Hj. Ihade).

Hasil belajar adalah kemampuan yang diperoleh individu setelah proses belajar berlangsung, yang dapat memberikan perubahan tingkah laku baik pengetahuan, 
pemahaman, sikap dan keterampilan siswa sehingga menjadi lebih baik dari sebelumnya (Purwanto, 2002: 82). Disimpulkan, hasil belajar dalam penelitian ini, adalah hasil yang diperoleh siswa setelah melakukan suatu kegiatan belajar dalam waktu tertentu, misalnya hasil belajar pada penguasaan pengetahuan atau keterampilan yang dikembangkan oleh mata pelajaran ditunjukkan dengan nilai tes atau angka nilai yang diberikan oleh guru.

Pembelajaran materi tematik menurut kurikulum 2013, khusunya tema 1 kelas V SD semester satu adalah organ gerak hewan dan manusia terdiri Sub tema 1 Organ gerak hewan. Sub tema 2 Manusia dan lingkungan. Sub tema 3 Lingkungan dan manfaat. Sub tema 4 Kegiatan berbasis proyek (Kementerian Pendidikan dan Kebudayaan RI, 2017). Dengan demikian, yang dibahas dalam penelitian ini adalah tema satu yaitu organ gerak hewan dan manusia.

Discovery learning didefinisikan sebagai proses pembelajaran yang terjadi bila siswa disajikan materi pembelajaran yang masih bersifat belum tuntas atau belum lengkap, sehingga menuntut siswa menyingkapkan beberapa informasi yang diperlukan untuk melengkapi materi ajar tersebut (Abidin, 2014: 175), dengan demikian, disimpulkan bahwa: Kegiatan belajar yang dilakukan untuk menemukan konsep materi pelajaran, menuntut guru lebih kreatif menciftakan situasi yang dapat membuat peserta didik belajar aktif menemukan pengetahuan sendiri, dengan proses pembelajaran yang terjadi bila siswa disajikan materi pembelajaran yang masih bersifat belum tuntas atau belum lengkap, sehingga menuntut siswa menyingkapkan beberapa informasi yang diperlukan untuk melengkapi materi ajar. Langkah-langkah sintak Discovery Learning yang dilaksanakan dalam penelitian ini adalah: (1) Stimulasi/pemberian rangsangan. (2) Identifikasi masalah. (3) Pengumpulan data. (4) Pengolahan data. (5) Pembuktian. (6) Menarik kesimpulan/generalisasi. (Syah dalam Abidin, 2014: 177-178).

\section{Metode}

Penelitian tindakan kelas ini menggunakan model dari Kemmis \& Taggart (dalam Sugiarti, 1997: 6), yaitu berbentuk spiral dari siklus yang satu ke siklus yang berikutnya. Setiap siklus meliputi planning (rencana), action (tindakan), observation (pengamatan), dan reflection (refleksi). Subyek penelitian ini adalah 12, lima orang laki-laki, tujuh orang berjenis perempuan. Data kualitatif dikumpul melalui lembar observasi aktivitas peserta didik dan kemampuan guru, sedang data kuantitatif dikumpul melalui tes hasil tindakan tiap akhir siklus.

Instrumen dalam mengumpulkan data: (1) Observasi adalah kegiatan pengumpulan data dengan berkunjung langsung ke objek yang akan diteliti, kemudian mencatat data-data yang dibutuhkan. Sedangkan teknik pengumpulan data dengan observasi digunakan bila peneliti berkenaan dengan perilaku manusia, proses kerja, gejala-gejala alam, dan bila responden yang diamati tidak terlalu besar (Sugiyono, 2016: 203). (2) Metode dokumentasi (3) Jurnal, jurnal adalah catatan harian (Departemen Pendidikan Nasional, 2008: 549). (4) Tes, bentuk tes essai butir soal yang mengandung pertanyaan atau tugas yang jawaban atau mengerjakan soal tersebut harus dilakukan dengan cara mengekspresikan pikiran peserta tes. (Asmawi Zaenul dan Noehi Nasution, 2005: 37 dalam Widoyoko, 2012: 82-83). Disimpulkan bahwa: Instrumen yang digunakan dalam penelitian ini adalah guru sendiri sebagai peneliti, dengan alat bantu berupa: (1) Lembar observasi kemampuan guru dalam merencanakan, mengelolah dan mengendalikan tindakan berbentuk cek list (2) lembar observasi aktivitas belajar peserta didik 
dalam melaksanakan tindakan berbentuk cek list, (3) lembar tes hasil belajar organ gerak hewan dan manusia berbentuk tes essai/uraian. (4) Dokumentasi tentang identitas peserta didik. (5) (Journal tentang catatan kehadiran peserta didik dalam melaksanakan tindakan dan tes).

Teknik analisa data kuantitatif hasil belajar secara deskriptif dengan menggunakan program SPSS Version -20. Teknik analisa data kualitatif kemampuan guru dan aktivitas peserta didik adalah dilakukan setelah pengumpulan data, dengan tahap kegiatanyaitu: Mereduksi data, menyajikan data, dan penarikan kesimpulan atau verifikasi (Milles \& Huberman, 1992). Mengamati kembali apa yang sudah dievaluasi hasil observasi, menarik kesimpulan yang menjadi titik kelemahan dan titik kelebihan pelaksanaan tindakan menurut hasil evaluasi terhadap hasil observasi dan hasil belajar peserta didik pada organ gerak hewan dan manusia. Menyimpulkan peningkatan secara positif kualitas hasil belajar peserta didik pada organ gerak hewan dan manusia, mennyimpulkan perubahan secara positif kemampuan guru dan aktifitas belajar peserta didik. Hasil refleksi ini dijadikan acuan dalam pelaksanaan siklus selanjutnya. Instrumen soal tes/isian obserasi dan sudah baik telah memenuhi syarat yaitu, valid dan reliabel.

Standarisasi kualitas penerimaan keberhasilan tindakan adalah: (1) Dibuktikan secara kuantitatif hasil belajar tema organ gerak hewan dan manusia secara keseluruhan, mengalami peningkatan secara positif, bilamana kualitas rerata skor minimal 70 atau kategori minimal cukup dengan ketuntasan belajar minimal $80 \%$ secara klasikal mendapat nilai KKM 70 pada siklus terakhir. (2) Didukung secara kualitatif kemampuan guru dan aktivitas peserta didik menunjukkan bahwa: Terdapat perubahan peningkatan secara positif, apabila menunjukkan kualitas persentase lebih besar $62,5 \%$ atau kriteria minimal baik pada siklus terakhir. (3) Selanjutnya ditunjang tingkat kehadiran siswa mencapai minimal $80 \%$.

\section{Hasil}

Secara grafik, perkembangan hasil penelitian dari siklus tiga dari pra siklus ke tiap siklus, menurut gambar berikut:

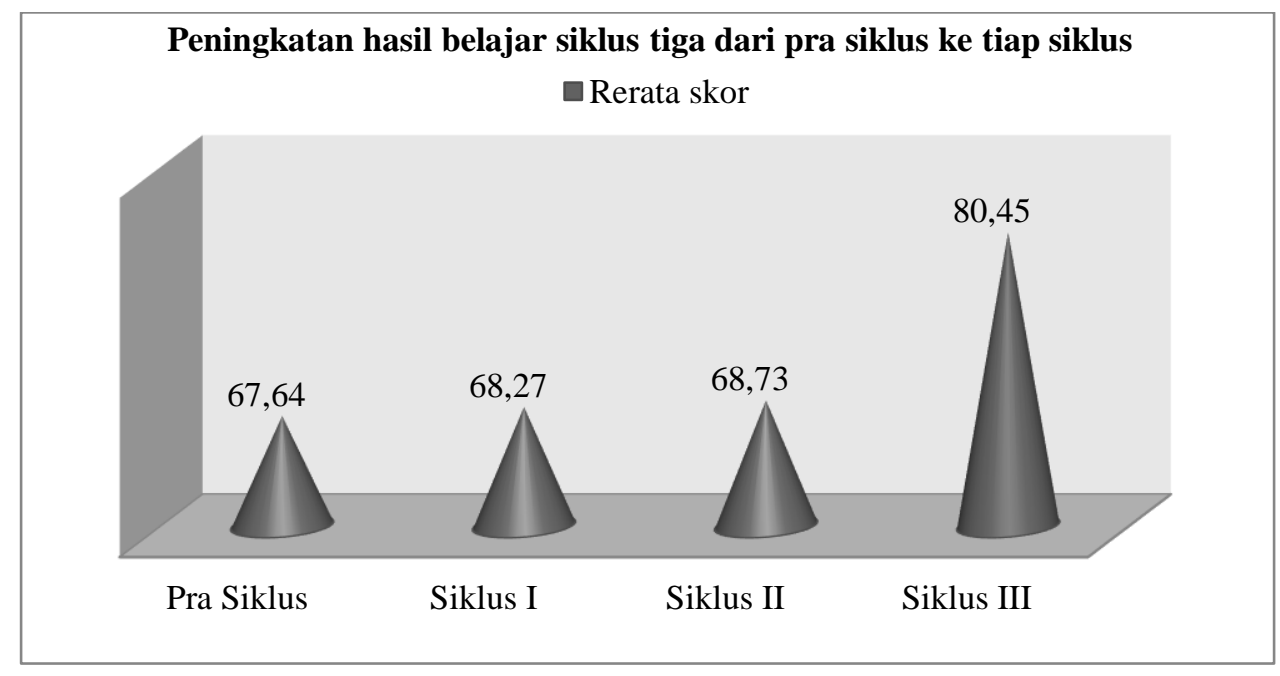

Gambar 1. Grafik peningkatan hasil belajar siklus tiga dari pra siklus tiap siklus 
Secara grafik, perkembangan dukungan kemampuan guru siklus tiga dari pra siklus ke tiap siklus, menurut gambar 2 berikut:

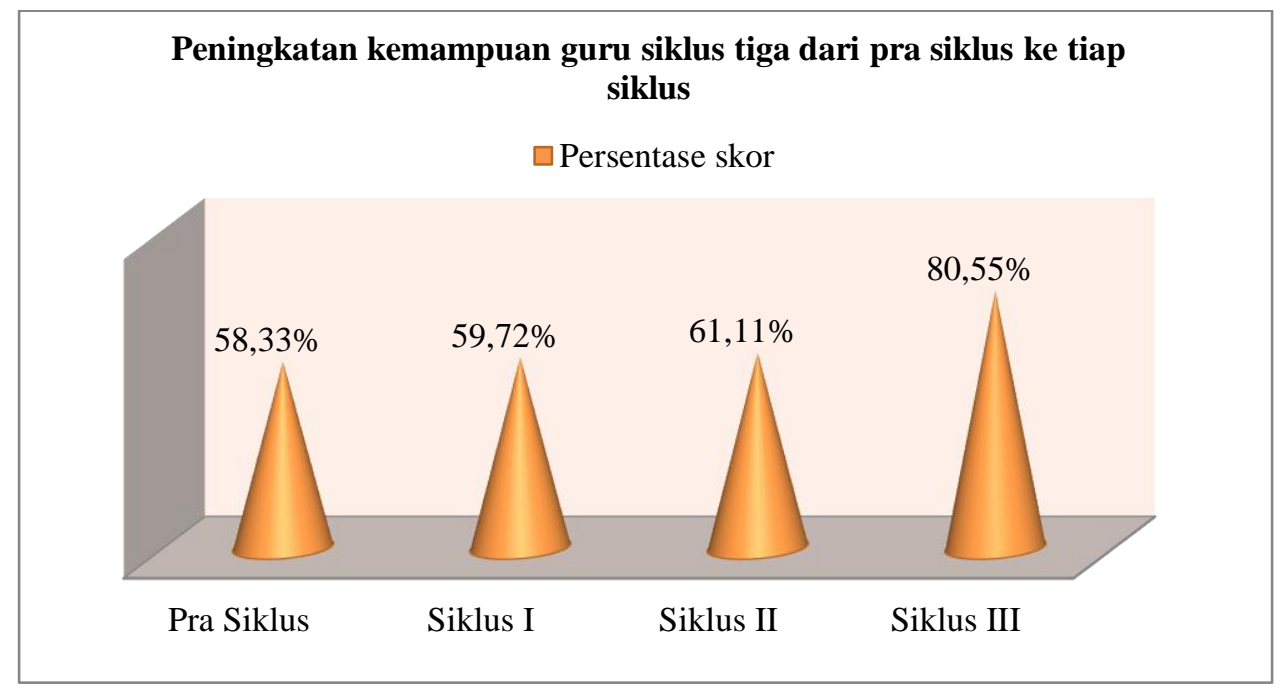

Gambar 2. Grafik peningkatan kemampuan guru siklus tiga dari pra siklus tiap siklus.

Secara grafik, perkembangan dukungan aktivitas belajar peserta didik siklus tiga dari pra siklus ke tiap siklus, menurut gambar 3 berikut:

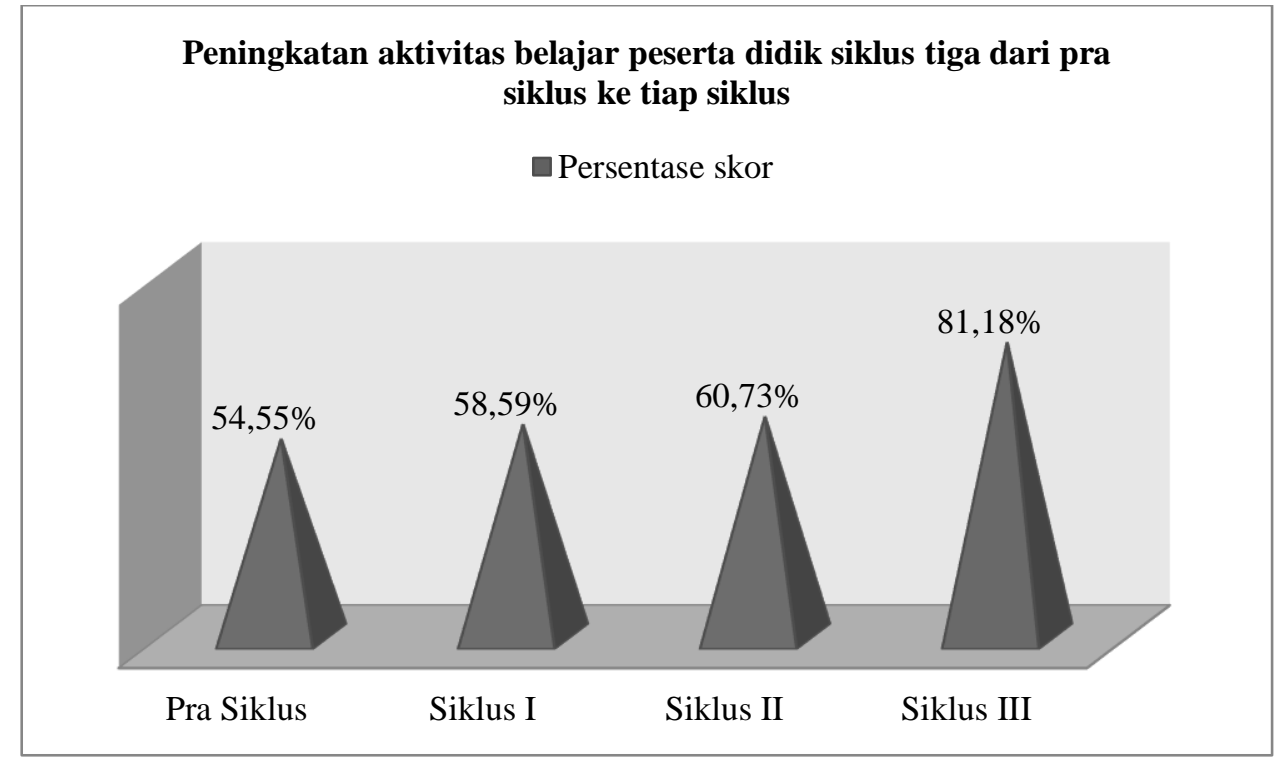

Gambar 3. Grafik peningkatan aktivitas belajar peserta didik siklus tiga dari pra siklus tiap siklus

\section{Pembahasan}

\section{Indikator keberhasilan tindakan siklus satu}

Indikator keberhasilan tindakan hasil belajar organ gerak hewan dan manusia peserta didik pada siklus satu, skor rata-rata adalah 68,27 kategori kurang dengan tuntas belajar 6 orang 54,5\% dari total jumlah siswa 11 orang, dibandingkan pra siklus rerata skor 67,64 kategori kurang, terjadi peningkatan tidak secara positif selisih 0,63, karena tidak meningkat kategori tetap kurang dan kualitas tidak mencapai standar indikator keberhasilan tindakan 
minimal 70 atau kategori cukup dengan tuntas belajar minimal 80,0\% yang mencapai nilai KKM 70 disiklus satu. Hal ini disebabkan masih banyaknya peserta didik siklus satu, temuan kelemahan dibandingkan kelebihan yaitu: Masih ada 5 orang subjek dengan 45,5\% yang belum mencapai nilai KKM 70 tema organ gerak hewan dan manusia. Baru 6 orang subjek dengan $54,5 \%$ sudah mencapai nilai KKM 70 tema organ gerak hewan dan amnusia. Kelemahan hasil belajar tema organ gerak hewan dan manusia peserta didik siklus satu tersebut, diperbaiki di siklus dua dengan upaya diberi motivasi dan semangat serta pemberian layannan remedial bagi peserta didik yang belum mencapai nilai KKM 70.

Indikator keberhasilan tindakan kemampuan guru siklus satu, masih banyak aspek tidak mencapai standar minimal baik. Tingkat kemampuan guru dengan frekuensi skor yang dicapai siklus satu adalah 43 dari jumlah total 72 dengan persentase 59,72\% kategori cukup. Jika dibadingkan pra siklus (pra penelitian) frekuensi skor yang dicapai adalah 42 dari jumlah total 72 dengan persentase 58,33\% kategori cukup. Terjadi peningkatan selisih 1,39\% kategori cukup tetap siklus satu dari pra siklus (pra penelitian). Belum terdapat perubahan peningkatan secara positif, karena belum menunjukkan kualitas persentase lebih besar 62,5\% atau kriteria minimal baik pada siklus satu. Disebabkan karena siklus satu, masih banyak beberapa kekurangan, kelemahan kemampuan guru siklus satu diperbaiki di siklus dua dengan upaya lebih memaksimalkan dalam memberikan stimulasi/pemberian rangsangan, identifikasi masalah, pengumpulan data pengolahan data, pembuktian, dan yang menjadi kelebihan dalam membimbing dalam menarik kesimpulan/generalisasi sudah baik dipertahankan supaya tidak menurun menjadi cukup atau kurang dan diusahakan agar dapat menjadi sangat baik.

Indikator keberhasilan tindakan observasi aktifitas belajar peserta didik siklus satu. Tingkat frekuensi skor yang dicapai siklus satu adalah 464 dari jumlah total 792 dengan persentase $58,59 \%$ kategori cukup. Jika dibadingkan pra siklus (pra penelitian) frekuensi skor yang dicapai adalah 432 dari jumlah total 792 dengan persentase 54,55\% kategori cukup. Terjadi peningkatan selisih 4,04\% kategori cukup tetap siklus satu dari pra siklus (pra penelitian). Belum terdapat perubahan peningkatan secara positif, karena belum menunjukkan kualitas persentase lebih besar $62,5 \%$ atau kriteria minimal baik pada siklus satu. Disebabkan siklus satu, masih banyak beberapa kekurangan, kelemahan aktivitas belajar peserta didik siklus satu diperbaiki di siklus dua dengan upaya memberi motivasi dan nasehat peserta didik yang 8 orang masih cukup dalam menyimak stimulasi dan pemberian rangsangan, identifikasi masalah, pengumpulan data, pembuktian, menarik kesimpulan dan generalisasi. Kelebihan dalam pengolahan data sudah baik dipertahankan supaya tidak menurun menjadi cukup atau kurang dan diusahakan agar dapat menjadi sangat baik.Indikator keberhasilan tindakan tingkat kehadiran peserta didik siklus satu adalah $100 \%$, semua peserta didik hadir semua dalam belajar dan tes dari pertemuan satu sampai pertemuan tiga.

\section{Indikator keberhasilan tindakan siklus dua}

Indikator keberhasilan tindakan hasil belajar organ gerak hewan dan manusia peserta didik pada siklus dua, masih banyak kekurangan yang ditemukan. Skor rata-rata siklus dua adalah 68,72 kategori kurang dengan tuntas belajar 6 orang dengan 54,5\% dari total 11 orang peserta didik. Jika dibandingkan hasil siklus satu rerata skor yang dicapai 68,27 kategori kurang, terjadi peningkatan selisih 0,45\%, kategori kurang tetap. Tidak mengalami 
peningkatan secara positif, karena belum mencapai kualitas rerata skor minimal 70 atau kategori minimal cukup dengan ketuntasan belajar belum mencapai minimal $80 \%$ secara klasikal mendapat nilai KKM 70 pada siklus dua. Hal ini disebabkan masih banyaknya peserta didik siklus dua, temuan kelemahan dibandingkan kelebihan yaitu: Masih ada 5 orang subjek dengan $45,5 \%$ yang belum mencapai nilai KKM 70 tema organ gerak hewan dan manusia. Baru 6 orang subjek dengan 54,5\% sudah mencapai nilai KKM 70. Kelemahan/kelebihan siklus dua tersebut, diperbaiki di siklus tiga dengan upaya dipertegas lagi motivasi dan semangat serta pemberian layannan remedial yang diberikan bagi peserta didik 5 orang yang belum mencapai nilai KKM 70, sedangkan 6 orang sudah mencapai nilai KKM 70 dipertahankan agar tidak menurun nilainya dan lebih ditingkatkan mencapai di atas KKM 70.

Indikator keberhasilan tindakan kemampuan guru siklus dua, masih banyak aspek tidak mencapai standar minimal baik. Tingkat kemampuan guru dengan frekuensi skor yang dicapai siklus dua adalah 44 dari jumlah total 72 dengan persentase $61,11 \%$ kategori cukup. Jika dibadingkan siklus satu frekuensi skor yang dicapai adalah 43 dari jumlah total 72 dengan persentase 59,72\% kategori cukup. Terjadi peningkatan selisih 1,39\% kategori cukup tetap siklus dua dari siklus satu. Belum terdapat perubahan peningkatan secara positif, karena belum menunjukkan kualitas persentase lebih besar $62,5 \%$ atau kriteria minimal baik pada siklus dua. Disebabkan karena siklus dua, masih banyak beberapa kekurangan yang ditemukan dibandingkan kelebihan. Kelemahan siklus dua diperbaiki di siklus tiga dengan upaya lebih ditingkatkan lagi kualitas dalam memberikan stimulasi/pemberian rangsangan, identifikasi masalah, pengumpulan data pengolahan data. Yang menjadi kelebihan dalam membimbing dalam pembuktian dan menarik kesimpulan/generalisasi sudah baik dipertahankan supaya tidak menurun menjadi cukup atau kurang dan diusahakan agar dapat menjadi sangat baik.

Indikator keberhasilan tindakan aktivitas belajar peserta didik siklus dua. Masih banyak kekurangan yang ditemukan. Tingkat frekuensi skor yang dicapai siklus dua adalah 481 dari jumlah total 792 dengan persentase $60,73 \%$ kategori cukup. Jika dibadingkan siklus satu frekuensi skor yang dicapai adalah 444 dari jumlah total 792 dengan persentase 58,59\% kategori cukup. Terjadi peningkatan selisih 2,14\% kategori cukup tetap siklus dua dari siklus satu. Belum terdapat perubahan peningkatan secara positif, karena belum menunjukkan kualitas persentase lebih besar $62,5 \%$ atau kriteria minimal baik pada siklus dua. Disebabkan karena aktivitas belajar peserta didik siklus dua, masih banyak beberapa kekurangan dibandingkan kelebihan. Kelemahan aktivitas belajar peserta didik siklus dua 7 orang masih cukup dalam pengumpulan data, pembuktian, menarik kesimpulan atau generalisasi. Kelebihan 4 orang dalam stimulasi/pemberian rangsangan, identifikasi, pengolahan data sudah baik. Dengan demikian, kelemahan aktivitas belajar peserta didik siklus dua diperbaiki di siklus tiga dengan upaya lebih dipertegas lagi pemberian motivasi dan nasehat peserta didik yang 7 orang masih cukup. Yang menjadi kelebihan 4 orang sudah baik dipertahankan supaya tidak menurun menjadi cukup atau kurang dan diusahakan agar dapat menjadi sangat baik.

Indikator keberhasilan tindakan tingkat kehadiran peserta didik dalam melaksanakan tindakan model pembelajaran Discovery Learning dan tes siklus dua adalah $100 \%$, semua peserta didik hadir semua dalam belajar dan tes dari pertemuan satu sampai pertemuan tiga.

\section{Indikator keberhasilan tindakan siklus tiga}

Indikator keberhasilan tindakan hasil belajar organ gerak hewan dan manusia peserta didik pada siklus tiga, tidak ditemukan lagi kekurangan. Skor rata-rata siklus tiga adalah 80,45 
kategori baik dengan tuntas belajar 9 orang dengan $81,8 \%$ dari total 11 orang peserta didik. Jika dibandingkan hasil siklus dua rerata skor yang dicapai 68,72 kategori kurang, terjadi peningkatan selisih $11,73 \%$, kategori meningkat baik siklus tiga dari kurang siklus dua. Telah mengalami peningkatan secara positif, karena telah mencapai kualitas rerata skor minimal 70 atau kategori minimal cukup dengan ketuntasan belajar belum mencapai minimal $80 \%$ secara klasikal mendapat nilai KKM 70 pada siklus tiga. Hal ini disebabkan hampir tidak ditemukan lagi kekurangan hasil belajar tema organ gerak hewan dan manusia peserta didik siklus dua, lebih banyak menjadi kelebihan yaitu: Hanya masih ada 2 orang subjek dengan $18,2 \%$ yang belum mencapai nilai KKM 70 tema organ gerak hewan dan manusia. Sudah 9 orang subjek sudah mencapai nilai KKM 70. Kelemahan/kelebihan hasil belajar siklus tiga tersebut, tidak perlu diperbaiki di siklus tiga dengan upaya pemberian layannan remedial yang diberikan bagi peserta didik 2 orang yang belum mencapai nilai KKM 70, karena sudah mencapai standar indikator keberhasilan tindakan, sedangkan 9 orang sudah mencapai nilai KKM 70 dipertahankan agar tidak menurun nilainya dan lebih ditingkatkan mencapai di atas KKM 70 hanya pada pembelajaran laiannya.

Sedangkan perkembangan peningkatan hasil belajar tema organ gerak hewan dan manusia dari pra siklus ke siklus satu sampai siklus tiga sebagai berikut: Siklus satu terjadi peningkatan tidak secara positif selisih 0,63 , karena tidak meningkat kategori tetap kurang dan kualitas tidak mencapai standar indikator keberhasilan tindakan minimal 70 atau kategori cukup dengan tuntas belajar minimal 80,0\% yang mencapai nilai KKM 70 disiklus satu. Siklus dua terjadi peningkatan tidak secara positif selisih $0,46 \%$, karena tidak meningkat kategori tetap kurang dan kualitas tidak mencapai standar indikator keberhasilan tindakan minimal 70 atau kategori cukup dengan tuntas belajar minimal 80,0\% yang mencapai nilai KKM 70 disiklus dua. Siklus tiga terjadi peningkatan secara positif selisih $11,73 \%$, karena kategori meningkat baik siklus tiga dari kurang siklus dua, telah mencapai kualitas rerata skor minimal 70 atau kategori minimal cukup dengan ketuntasan belajar belum mencapai minimal $80 \%$ secara klasikal mendapat nilai KKM 70 pada siklus tiga.

Indikator keberhasilan tindakan kemampuan guru siklus tiga, tidak ditemukan lagi kekurangan kemampuan guru siklus tiga. Tingkat frekuensi skor yang dicapai siklus tiga adalah 58 dari jumlah total 72 dengan persentase $80,55 \%$ kategori baik. Jika dibadingkan siklus dua frekuensi skor yang dicapai adalah 44 dari jumlah total 72 dengan persentase $61,11 \%$ kategori cukup. Terjadi peningkatan selisih 19,44\% kategori baik siklus tiga dari cukup siklus dua. Telah terdapat perubahan peningkatan secara positif, karena telah menunjukkan kualitas persentase lebih besar 62,5\% atau kriteria minimal baik pada siklus tiga. Disebabkan karena siklus tiga, tidak ditemukan lagi kekurangan dibandingkan kelebihan rata-rata sudah menjadi baik atau sangat baik. Kelebihan sudah baik dipertahankan supaya tidak menurun menjadi cukup atau kurang dan diusahakan agar dapat menjadi sangat baik hanya pada pembelajaran lainnya.

Sedangkan perkembangan peningkatan kemampuan guru dari pra siklus ke siklus satu sampai siklus tiga sebagai berikut: Siklus satu belum terdapat perubahan peningkatan secara positif, selisih 1,39\% kategori cukup tetap siklus satu dari pra siklus (pra penelitian), karena belum menunjukkan kualitas persentase lebih besar $62,5 \%$ atau kriteria minimal baik pada siklus satu. Siklus dua belum terdapat perubahan peningkatan secara positif selisih 1,39\% kategori cukup tetap siklus dua dari siklus satu, karena belum menunjukkan kualitas persentase lebih besar $62,5 \%$ atau kriteria minimal baik pada siklus dua. Siklus tiga terjadi 
peningkatan selisih 19,44\% kategori baik siklus tiga dari cukup siklus dua. Telah terdapat perubahan peningkatan secara positif, karena telah menunjukkan kualitas persentase lebih besar $62,5 \%$ atau kriteria minimal baik pada siklus tiga.

Indikator keberhasilan tindakan aktivitas belajar peserta siklus tiga. Tingkat frekuensi skor yang dicapai siklus tiga adalah 635 dari jumlah total 792 dengan persentase $81,18 \%$ kategori sangat baik. Jika dibadingkan siklus dua frekuensi skor yang dicapai adalah 481 dari jumlah total 792 dengan persentase 60,73\% kategori cukup. Terjadi peningkatan selisih $20,45 \%$ kategori meningkat sangat baik siklus tiga dari cukup siklus dua. Telah terdapat perubahan peningkatan secara positif, karena telah menunjukkan kualitas persentase lebih besar $62,5 \%$ atau kriteria minimal baik pada siklus tiga. Disebabkan karena siklus tiga, tidak ditemukan lagi kekurangan dibandingkan kelebihan rata-rata sudah menjadi lebih baik atau sangat baik. Kelemahan aktivitas belajar peserta didik siklus tiga tidak perlu diperbaiki di siklus selanjutnya, karena sudah mencapai standar indikator keberhasilan tindakan. Kelebihan sudah baik dipertahankan supaya tidak menurun menjadi cukup atau kurang dan diusahakan agar dapat menjadi sangat baik hanya pada pembelajaran lainnya (Indah, Suhardi, \& Ramadhana, 2021).

Sedangkan perkembangan peningkatan aktivitas belajar peserta didik dari pra siklus ke siklus satu sampai siklus tiga sebagai berikut: Siklus satu dan dua belum terdapat perubahan peningkatan secara positif karena persentase dan kategori belum tercapai standar, meningkat selisih 4,04\% kategori cukup tetap siklus satu dari pra siklus (pra penelitian), peningkatan selisih $2,14 \%$ kategori cukup tetap siklus dua dari siklus satu. Telah terdapat perubahan peningkatan secara positif selisih 20,45\% kategori meningkat sangat baik siklus tiga dari cukup siklus dua. Karena telah menunjukkan kualitas persentase lebih besar $62,5 \%$ atau kriteria minimal baik pada siklus tiga. Indikator keberhasilan tindakan kehadiran peserta didik adalah $100 \%$, semua peserta didik hadir semua pertemuan satu sampai pertemuan tiga.

\section{Kesimpulan}

Disimpulkan bahwa model pembelajaran discovery learning dapat meningkatkan kemampuan memahami tema organ gerak hewan dan manusia siswa kelas V SD Inpres Ampiri Kabupaten Barru, meningkat secara positif selisih 11,72\% dan kategori baik siklus tiga dari kurang siklus dua. Perubahan secara positif dukungan kemampuan guru meningkat selisih $19,44 \%$ dan kategori baik siklus tiga dari cukup siklus dua. Perubahan secara positif aktivitas peserta didik meningkat selisih 20,45\% dan kategori baik siklus tiga dari cukup siklus dua.

Model pembelajaran discovery learning dapat dijadikan sebagai variasi dari model pembelajaran yang lainnya karena model ini dapat meningkatkan hasil belajar siswa. Perubahan secara positif aktivitas peserta didik dijadikan motivasi dalam peningkatan keaktifan pada pembelajaran selanjutnya. Peningkatan secara positif kemampuan guru dijadikan motivasi guru lebih membimbing peserta didik.

\section{Ucapan Terima Kasih}




\section{Referensi}

Abidin, Y. (2014). Desain Sistem Pembelajaran Dalam Konsteks Kurikulum 2013. Bandung: PT Refika Aditama

Arikunto, S. (2007). Penelitian Tindakan Kelas. Jakarta : Bumi Aksara

Indah, O. D., Suhardi, S., \& Ramadhana, M. A. (2021). Pendampingan dan praktek pembuatan media pembelajaran bagi mahasiswa PGSD Universitas Cokroaminoto Palopo. Jurnal Abdimas Indonesia, 1(1), 12-17. Retrieved From Https://Www.DmiJournals.Org/Jai/Article/View/45

Kementerian Pendidikan Dan Kebudayaan. (2017). Tema 1. Organ Gerak Hewan Dan Manusia Buku Tematik Terpadu Kurikulum 2013, Buku Guru SD/MI Kelas V. Revisi 2017. Jakarta: Kementerian Pendidikan Dan Kebudayaan

Kementerian Pendidikan Dan Kebudayaan. (2017). Tema 2. Organ Gerak Hewan Dan Manusia Buku Tematik Terpadu Kurikulum 2013, Buku Siswa SD/MI Kelas V. Revisi 2017. Jakarta: Kementerian Pendidikan Dan Kebudayaan

Milles \& Huberman. (1992). Analisis Data Kualitatif. Terjemahan Rohendi Rohidi. Jakarta: Universitas Indonesia

Sani, A. R. (2015). Pembelajaran Saintifik Utnuk Implementasi Kurikulum 2013. Jakarta: PT Bumi Aksara

Purwanto, N. M. (2002). Psikologi Pendidikan. Bandung: Remaja Rosda Karya

Sugiarti, T. (1997). Penelitian Tindakan Kelas. Makalah Disajikan Dalam Pelatihan Peningkatan Kualifikasi Guru S1 PGSD. Universitas Jember

Sugiyono. (2016). Metode Penelitian Pendidikan. Bandung: Alfabeta

Widoyoko, E. P. S. (2012). Teknik Penyusunan Instrumen Penelitian. Yokyakarta: Pustaka Pelajar 